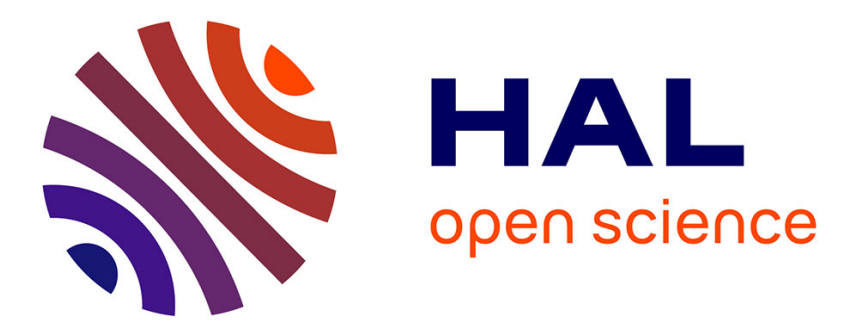

\title{
Hepatic glucokinase is induced by dietary carbohydrates in rainbow trout, gilthead seabream, and common carp
}

Stéphane Panserat, Françoise Médale, C. Blin, Jeanine Breque, Christiane Vachot, Elisabeth Plagnes Juan, E. Gomes, R. Krishnamoorthy, Sadasivam S. Kaushik

\section{To cite this version:}

Stéphane Panserat, Françoise Médale, C. Blin, Jeanine Breque, Christiane Vachot, et al.. Hepatic glucokinase is induced by dietary carbohydrates in rainbow trout, gilthead seabream, and common carp. AJP - Regulatory, Integrative and Comparative Physiology, 2000, 278 (5), pp.R1164-R1170. hal-02694682

\section{HAL Id: hal-02694682 \\ https://hal.inrae.fr/hal-02694682}

Submitted on 1 Jun 2020

HAL is a multi-disciplinary open access archive for the deposit and dissemination of scientific research documents, whether they are published or not. The documents may come from teaching and research institutions in France or abroad, or from public or private research centers.
L'archive ouverte pluridisciplinaire HAL, est destinée au dépôt et à la diffusion de documents scientifiques de niveau recherche, publiés ou non, émanant des établissements d'enseignement et de recherche français ou étrangers, des laboratoires publics ou privés. 
S. Panserat, F. Médale, C. Blin, J. Brèque, C. Vachot, E. Plagnes-Juan, E. Gomes, R. Krishnamoorthy and S. Kaushik

Am J Physiol Regulatory Integrative Comp Physiol 278:1164-1170, 2000.

You might find this additional information useful...

This article cites 39 articles, 11 of which you can access free at:

http://ajpregu.physiology.org/cgi/content/full/278/5/R1164\#BIBL

This article has been cited by 14 other HighWire hosted articles, the first 5 are:

Glucose homeostasis is impaired by a paradoxical interaction between metformin and insulin in carnivorous rainbow trout

S. Polakof, S. Skiba-Cassy and S. Panserat

Am J Physiol Regulatory Integrative Comp Physiol, December 1, 2009; 297 (6): R1769-R1776.

[Abstract] [Full Text] [PDF]

Metformin improves postprandial glucose homeostasis in rainbow trout fed dietary carbohydrates: a link with the induction of hepatic lipogenic capacities?

S. Panserat, S. Skiba-Cassy, I. Seiliez, M. Lansard, E. Plagnes-Juan, C. Vachot, P. Aguirre, L.

Larroquet, G. Chavernac, F. Medale, G. Corraze, S. Kaushik and T. W. Moon

Am J Physiol Regulatory Integrative Comp Physiol, September 1, 2009; 297 (3): R707-R715.

[Abstract] [Full Text] [PDF]

Altered dietary carbohydrates significantly affect gene expression of the major glucosensing components in Brockmann bodies and hypothalamus of rainbow trout

S. Polakof, S. Panserat, E. Plagnes-Juan and J. L. Soengas

Am J Physiol Regulatory Integrative Comp Physiol, October 1, 2008; 295 (4): R1077-R1088.

[Abstract] [Full Text] [PDF]

Low temperature directly activates the initial glycerol antifreeze response in isolated rainbow smelt (Osmerus mordax) liver cells

K. A. Clow, K. V. Ewart and W. R. Driedzic

Am J Physiol Regulatory Integrative Comp Physiol, September 1, 2008; 295 (3): R961-R970.

[Abstract] [Full Text] [PDF]

Dietary carbohydrates induce changes in glucosensing capacity and food intake of rainbow trout

S. Polakof, J. M. Miguez and J. L. Soengas

Am J Physiol Regulatory Integrative Comp Physiol, August 1, 2008; 295 (2): R478-R489.

[Abstract] [Full Text] [PDF]

Medline items on this article's topics can be found at http://highwire.stanford.edu/lists/artbytopic.dtl

on the following topics:

Biochemistry .. Hexokinase

Biochemistry .. Glucokinase

Physiology .. Salmoniformes

Medicine .. Diet

Medicine .. Dietary Carbohydrates

Veterinary Science .. Trout

Updated information and services including high-resolution figures, can be found at:

http://ajpregu.physiology.org/cgi/content/full/278/5/R1164

Additional material and information about American Journal of Physiology - Regulatory, Integrative and

Comparative Physiology can be found at:

http://www.the-aps.org/publications/ajpregu

This information is current as of November 9, 2010 .

The American Journal of Physiology - Regulatory, Integrative and Comparative Physiology publishes original investigations that illuminate normal or abnormal regulation and integration of physiological mechanisms at all levels of biological organization, ranging from molecules to humans, including clinical investigations. It is published 12 times a year (monthly) by the American Physiological

Society, 9650 Rockville Pike, Bethesda MD 20814-3991. Copyright ( 2000 by the American Physiological Society. ISSN: 0363-6119,

ESSN: 1522-1490. Visit our website at http://www.the-aps.org/. 


\title{
Hepatic glucokinase is induced by dietary carbohydrates in rainbow trout, gilthead seabream, and common carp
}

\author{
S. PANSERAT, ${ }^{1}$ F. MÉDALE, ${ }^{1}$ C. BLIN, ${ }^{2} J$. BRÈQUE, ${ }^{1}$ C. VACHOT, ${ }^{1}$ \\ E. PLAGNES-J UAN, ${ }^{1}$ E. GOMES, ${ }^{3}$ R. KRISHNAMOORTHY, ${ }^{2}$ AND S. KAUSHIK ${ }^{1}$ \\ ${ }^{1}$ Laboratory of Fish Nutrition, Institut National de la Recherche Agronomiquel nstitut Français de \\ Recherche pour l'Exploitation de la Mer, 64310 St-Péesur-Nivelle; 'I nstitut National de la Santé \\ et de la Recherche Médicale U 458, Hôpital Robert Debré, 75019 Paris, France; and 3Instituto \\ Ciencas Biomedicas Abel Salazar, Universidade do Porto, 4000 Porto, Portugal
}

\begin{abstract}
Panserat, S., F. Médale, C. Blin, J . Brèque, C. Vachot, E. Plagnes-J uan, E. Gomes, R. Krishnamoorthy, and S. Kaushik. Hepatic glucokinase is induced by dietary carbohydrates in rainbow trout, gilthead seabream, and common carp. AmJ Physiol Regulatory I ntegrativeComp Physiol 278: R1164-R 1170, 2000.-Glucokinase (GK) plays a central role in glucose homeostasis in mammals. The absence of an inducible GK has been suggested to explain the poor utilization of dietary carbohydrates in rainbow trout. In this context, we analyzed GK expression in three fish species (rainbow trout, gilthead seabream, and common carp) known to differ in regard to their dietary carbohydrate tolerance. Fish were fed for $10 \mathrm{wk}$ with either a diet containing a high level of digestible starch ( $>20 \%$ ) or a diet totally deprived of starch. Our data demonstrate an induction of GK gene expression and GK activity by dietary carbohydrates in all three species. These studies strongly suggest that low dietary carbohydrate utilization in rainbow trout is not due to the absence of inducible hepatic GK as previously suggested. Interestingly, we also observed a significantly lower GK expression in common carp (a glucose-tolerant fish) than in rainbow trout and gilthead seabream, which are generally considered as glucose intolerant. These data suggest that other biochemical mechanisms are implicated in the inability of rainbow trout and gilthead seabream to control blood glucose closely.

glucokinase expression; fish nutrition
\end{abstract}

USE OF CARBOHYDRATES as digestible energy sources in fish diets bears economic significance in aquaculture (44): when carbohydrates are not provided in the diet, more proteins are catabolized for energy and for the synthesis of glucose, which impairs protein retention and increases nitrogen rel ease into the environment (8, 34, 44). However, in species such as rainbow trout (Oncorhynchus mykiss), oral administration of glucose as well as ingestion of high carbohydrate diet result in poor dietary glucose utilization associated with a prolonged hyperglycemia $(2,5,25)$. In contrast, common carp (Cyprinus carpio) easily use high levels of dietary carbohydrates and gilthead seabream (Sparus aurata) have an intermediary phenotype $(11-13,44)$.

\footnotetext{
The costs of publication of this article were defrayed in part by the payment of page charges. The article must therefore be hereby marked "advertisement" in accordance with 18 U.S.C. Section 1734 solely to indicate this fact.
}

One of the earlier hypotheses to explain the difficulty of rainbow trout to use high levels of dietary carbohydrates is a deficiency of the liver to actively convert the intracellular glucose to glucose-6-phosphate when concentrations of the hexose are raised. Although glucose phosphorylation catalyzed by low Michaelis constant $\left(\mathrm{K}_{\mathrm{m}}\right)$-hexokinase enzymes (HKs; EC 2.7.1.1) (43) is known to be active in glucose-dependent tissues (heart, brain) of fish (20), it has been suggested that the inducible HK IV, commonly known as "glucokinase" or "high- $K_{m}$ hexokinase" (GK) is absent in the liver of rainbow trout $(7,13,21,22)$. In mammals, GK is expressed only in liver (under the control of insulin), in the insulin-secreting $(\beta)$ and glucagon-secreting $(\alpha)$ cells of the pancreas, and in some rare neuroendocrine cells $(18,30)$. Current biochemical evidence points out that hepatic and pancreatic $\beta$-cell GKs play a major role in glucose homeostasis in controlling the rate of hepatic glucose utilization and insulin secretion by pancreatic $\beta$-cells $(9,15,19,24,28,41)$. On the basis of these studies, it has also been suggested that the low hepatic utilization of dietary glucose in rainbow trout is dueto the absence of inducibleGK expression $(7,22,35$, 40). However, a GK enzyme has been partially purified in Atlantic salmon (Salmo salar) and Atlantic halibut (Hippogl ossus hippogl ossus) $(38,39$ ) and has even been found to be inducible by dietary carbohydrates in the liver of Atlantic salmon $(4,38)$. The objective of this study was to evaluate the nutritional control of GK in rainbow trout, which are known to be glucose intolerant with persistent hyperglycemia $(2,5,25)$.

Recently, we cloned partial and complete GK cDNAs in livers of rainbow trout, common carp, and gilthead seabream $(3,26)$. The fish GK CDNA sequences were highly similar to mammalian GK CDNAs, suggesting strongly that these GK sequences correspond to functional GK enzymes. As one of the main systems regulating GK activity in mammals is alteration in its gene expression by dietary carbohydrates through an indirect action of insulin $(17,30)$, our objective was to study the nutritional regulation of hepatic GK expression. GK expression was analyzed both at the biochemical and molecular levels (activity and mRNA) in liver of rainbow trout fed with or without carbohydrates. Studies were also undertaken with gilthead seabream and common carp to test if the species-distinct capacities of 
glucose utilization $(11-13,44)$ could be linked to variable GK expression capacities. Hepatic GK expression was measured at $6 \mathrm{~h}$ after feeding, known as the moment of the highest peak of glycemia in thesespecies $(2,5,11$, and our own observations) and at $24 \mathrm{~h}$ after feeding, considered as a postabsorptive state $(2,5,11)$.

\section{MATERIAL AND METHODS}

Fish and diets. Rainbow trout were reared at the Institut National de la Recherche Agronomique experimental fish farm (Donzacq, France), and common carp and gilthead seabream were reared at the Instituto Ciencas Biomedicas Abel Salazar experimental facilities (Vila Real and Olhao, Portugal). For each species, two experimental diets were formulated: one contained a high level of digestible carbohydrates (starch $>20 \%$ ) supplied by dehulled extruded peas, the other was free of carbohydrates (starch $<0.2 \%$ ) (Table 1 ). Triplicate groups of juvenile immature fish (body weight range at the end of the growth period $\sim 150 \mathrm{~g}$ ) were grown for 10 wk at $18^{\circ} \mathrm{C}$ during spring (rainbow trout and common carp) or $25^{\circ} \mathrm{C}$ during autumn (gilthead seabream) under natural photoperiods. They were fed the respective diets twice a day to near satiation. On the day of sampling, fish were fed once, and then nine fish from each experimental group were killed 6 and $24 \mathrm{~h}$ after the meal. Blood was sampled from the caudal vein, centrifuged $(3,000 \mathrm{~g})$, and analyzed for plasma glucose concentration using a glucose analyzer (Beckman II). A part of the liver (approximately onequarter) was quickly excised and used for immediate determination of enzyme activity. The remaining part of the liver and a piece of white muscle were freeze clamped in liquid nitrogen and stored at $-80^{\circ} \mathrm{C}$.

Table 1. Formulation and chemical composition of the experimental diets

\begin{tabular}{|c|c|c|c|c|c|c|}
\hline \multirow[b]{2}{*}{ Diets } & \multicolumn{2}{|c|}{ Rainbow Trout } & \multicolumn{2}{|c|}{ Common Carp } & \multicolumn{2}{|c|}{ Gilthead Seabream } \\
\hline & + & - & + & - & + & - \\
\hline \multicolumn{7}{|c|}{ Ingredients, \% } \\
\hline $\begin{array}{l}\text { Extruded dehulled } \\
\text { peas }\end{array}$ & 40 & 0 & 46 & 0 & 40 & 0 \\
\hline $\begin{array}{l}\text { Norvegian herring } \\
\text { meal (CP, 70\%) }\end{array}$ & 25 & 73 & - & 86 & 41 & 87 \\
\hline Wheat bran & 7.1 & 0 & 0 & 0 & 0 & 0 \\
\hline Soybean meal & & & & & & \\
\hline (CP, 48\%) & 0 & 0 & 18 & 0 & 7 & 0 \\
\hline CPSP G (CP, 70\%) & 1.4 & 15 & 0 & 0 & 0 & 0 \\
\hline CPSP (CP, 80\%) & 12.6 & 0 & 0 & 50 & 0 & 5 \\
\hline Fish oil & 10.9 & 9 & 9 & 3 & 6 & 2 \\
\hline Mineral mix & 1 & 1 & 3 & 3 & 3 & 3 \\
\hline Vitamin mix & 1 & 1 & 1 & 1 & 1 & 1 \\
\hline Binder & 1 & 1 & 2 & 2 & 2 & 2 \\
\hline \multicolumn{7}{|c|}{ Analytic composition } \\
\hline DM, \% & 85.5 & 92.7 & 93.6 & 93.0 & 91.6 & 91.3 \\
\hline $\mathrm{CP}, \% \mathrm{DM}$ & 39.5 & 54.8 & 33.6 & 63.8 & 45.5 & 67.7 \\
\hline Crudelipid, \%DM & 16.6 & 18.3 & 12.2 & 13.0 & 12.2 & 16.2 \\
\hline Digestible starch, & 204 & $<02$ & test & 20 & 21 & $<02$ \\
\hline Gross energy, & 20.7 & -0.2 & & & 1.1 & \\
\hline $\mathrm{kJ} / \mathrm{g} \mathrm{DM}$ & 22.1 & 23.1 & 20.8 & 21.4 & 21.1 & 21.8 \\
\hline
\end{tabular}

+ And -, with or without carbohydrate, respectively; $C P$, crude protein; DM, dry matter; CPSP, fish soluble concentrate protein; CPSP G; fish soluble concentrate protein with high fat level from Sopropèche. Dehulled peas (Aquatex) from Stotexpo. Mineral mix and vitamin mix per National Research Council (23).
Enzyme assays. A fresh sample of liver (500 mg) was homogenized (dilution 1:10) in ice-cold buffer [in mM: 80 Tris, 5 EDTA, 2 1,4-dithiothreitol, 1 benzamidine, 1 4-(2-aminoethyl)benzenesulfonyl fluoride, $\mathrm{pH}$ 7.6]. The homogenate was centrifuged for $5 \mathrm{~min}$ at $900 \mathrm{~g}$. Enzyme activities were measured at $37^{\circ} \mathrm{C}$ by coupling ribulose-5-phosphate formation from glucose-6-phosphate to the reduction of NADP using purified glucose-6-phosphate dehydrogenase (Sigma) and 6-phosphogluconate dehydrogenase (Sigma) as coupling enzymes $(17,38)$. One unit of enzyme activity was defined as the amount that phosphorylates $1 \mu \mathrm{mol}$ glucose/min. The GK activity of the crude homogenate was estimated by the standard method subtracting the rate of NADPH formation (at $340 \mathrm{~nm}$ ) in the presence of $1 \mathrm{mM}$ glucose (scoring low- $\mathrm{K}_{\mathrm{m}}$ HK activities) from that at $100 \mathrm{mM}$ glucose (scoring total HK activities) proposed for mammals and Atlantic sal mon (4, 17, 38). Analysis of GK activity in muscle and the effects of a specific GK inhibitor were performed on frozen samples. This assay for measuring GK activity on frozen samples necessitated correction by measuring glucose dehydrogenase activity (EC 1.1.1.47) (38) [the commercial enzymes and ATP were omitted in this assay as described previously $(4,38)]$. The glucose dehydrogenase is a moderately active microsomal enzyme in fish liver that can introduce significant bias into GK measurements on frozen tissue (36-38) but not in fresh samples (personal observation). During the GK activity inhibition test, GK activity was measured as described above in the presence of 5,10 , and $25 \mathrm{mM} \mathrm{N}$-acetyl-glucosamine (Sigma), a known competitive inhibitor of GK (1). Galactosamine (Sigma) was used as a negative control.

Northern analysis. Total RNA was extracted from each tissue using the method of Chomczynski and Sacchi (6). Twenty micrograms of extracted total RNA samples were electrophoresed in $1 \%$ agarose gels containing $5 \%$ formaldehydeand capillary transferred onto nylon membrane (Hybond$\mathrm{N}^{+}$, Amersham). Membranes were hybridized with ${ }^{32} \mathrm{P}$ labeled DNA probes labeled by random priming (Stratagene) recognizing GK for the three fish species (3). (GenBank accession numbers for the GK-like probes are AF 053330 for gilthead seabream; AF 053331 for rainbow trout; AF 053332 for common carp.) Membranes were also hybridized with a carp $16 \mathrm{~S}$ ribosomal RNA probe (the 3021- to 3100-bp fragment. GenBank accession number MICCCG) to check for equivalent RNA loading and response specificity. After stringent washing, the membranes were exposed to X-ray film, and the resulting images were quantitated using Visio-Mic II software (Genomic).

RT-PCR analysis. CDNA was obtained by annealing $2 \mu \mathrm{g}$ of total RNA with $1 \mu \mathrm{g}$ of random primers and incubating with Avian Myeloblastosis Virus reverse transcriptase (Boehringer, Roche Molecular Biochemicals) for $1 \mathrm{~h}$ at $42^{\circ} \mathrm{C}$. GK CDNA was amplified by PCR using specific primers chosen in the partial GK cDNA sequences (3): 1) 5'-TGATGTTGGTGAAGGTGGGG-3' and 5'-TTCAGTAGGATGCCCTTGTC-3' for rainbow trout, 2) 5'-TGTGATGCTGGTGAAGGTGG-3' and 5'-TGATGTTGGTGAAGGTGGGG-3' for gilthead seabream, and 3) 5'-AGTGATGCTGGTCAAAGTGG-3' and 5'GCTTCTTATGTTTCAGATTA-3' for common carp. The PCR reaction was carried out in a final volume of $25 \mu \mathrm{l}$ containing $1.5 \mathrm{mM} \mathrm{M} \mathrm{gCl} 2$ and 4 pmol of each primer, $2 \mu \mathrm{CDNA}$, and $1 \mathrm{U}$ of Taq polymerase (Boehringer, Roche Molecular Biochemicals). The annealing temperature was $51^{\circ} \mathrm{C}$, except for rainbow trout $\left(55^{\circ} \mathrm{C}\right)$. Number of cycles was 35 composed of $20 \mathrm{~s}$ for hybridization, $20 \mathrm{~s}$ for el ongation $\left(\right.$ at $72^{\circ} \mathrm{C}$ ), and $20 \mathrm{~s}$ for denaturation (at $94^{\circ} \mathrm{C}$ ). Negative controls without reverse transcriptase, mRNA, and cDNAs were performed to avoid contaminations. The PCR products were characterized by 
Table 2. Hepatic GK activities in threefish species fed diets with or without carbohydrates

\begin{tabular}{|c|c|c|c|c|}
\hline Species & Diets & \multicolumn{3}{|c|}{ GK Activities (Glycemia mM), Hours after Meal } \\
\hline Rainbow trout & + Carbohydrates & ND & $36.7 \pm 12.5(10.5 \pm 2.5)$ & $55.2 \pm 13.1^{d}(7.5 \pm 2.1)^{d}$ \\
\hline \multirow[t]{2}{*}{ Gilthead seabream } & + Carbohydrates & ND & $29.9 \pm 12.0(8.5 \pm 1.9)$ & $4.0 \pm 1.9^{f}(5.4 \pm 1.4)^{d}$ \\
\hline & - Carbohydrate & ND & $1.0 \pm 0.7 c(8.4 \pm 2.9)$ & $0.7 \pm 0.3(9.3 \pm 4.5)^{a}$ \\
\hline \multirow[t]{2}{*}{ Common carp } & + Carbohydrates & $1.5 \pm 0.9^{\mathrm{e}}(\mathrm{ND})$ & $9.7 \pm 5.8(3.5 \pm 1.6)$ & $1.8 \pm 1.4 \mathrm{e}(2.5 \pm 0.4)$ \\
\hline & - Carbohydrate & $1.1 \pm 0.8$ (ND) & $1.8 \pm 1.2^{\mathrm{C}}(2.8 \pm 1.1)$ & $1.6 \pm 0.5(2.8 \pm 1.7)$ \\
\hline
\end{tabular}

Data are means of 9 observations (9 fishes) \pm SD in $\mathrm{mU} / \mathrm{mg}$ protein. Data are measured on fresh tissues. GK, glucokinase. aP $<0.05$, bP $<0.01$, cP $<0.001$, compared with values of fish fed with carbohydrates; ${ }^{d} \mathrm{P}<0.05$, eP $<0.01,{ }^{\text {f }} \mathrm{P}<0.001$, compared with values at $6 \mathrm{~h}$. ND, not determined.

hybridization with the labeled GK probes and by sequencing according to Sanger et al. (32).

Data analysis. Statistical analysis between two series of data (means \pm SD) was determined using an unpaired two-tailed computerized Student's t-test (Statview software). Differences were considered significant at the level of $5 \%$.

\section{RESULTS}

In each species, growth rates of fish fed with or without carbohydrates were comparable: daily growth coefficients [(final body weight $t_{1 / 3}$ - initial body $\left.\mathrm{wt}_{1 / 3}\right) /(\mathrm{n}$ days) $\cdot 100]$ were $3.31 \pm 0.09$ (means \pm SD) and $3.36 \pm$ 0.06 for rainbow trout, $2.36 \pm 0.25$ and $2.45 \pm 0.30$ for common carp, and $1.83 \pm 0.09$ and $1.95 \pm 0.08$ for gilthead seabream, respectively ( $n=9$ fish/group). After 10 wk of feeding, no significant effects of dietary carbohydrates were seen in terms of growth performance or feed utilization in any of the species. As all fish were fed nutritionally adequate diets and liver samplings made in fish well adapted to the respective diets, comparative analysis between fish groups concerning the effect of dietary carbohydrates on the regulation of HK enzymes expression is possible.

In the present study, enzyme activity measurements were made at a common temperature of $37^{\circ} \mathrm{C}$, allowing comparisons between species in terms of potential activities. GK activities measured in livers of fish fed with or without carbohydrates at 6 and $24 \mathrm{~h}$ after feeding are reported in Table 2. At $6 \mathrm{~h}$ after a meal, GK activities were significantly higher in livers of all the three species of fish fed a high-carbohydrate diet than in those fed without carbohydrates (Table 2): 11-fold in rainbow trout, 30-fold in gilthead seabream, and 5-fold in common carp. GK activity in common carp was significantly lower than in gilthead seabream and rainbow trout (Student's t-test, $\mathrm{P}<0.001$ ). But com- pared with GK activity measured $3 \mathrm{~h}$ after a meal, our data show a definiteinduction of carp GK activity at $6 \mathrm{~h}$ after feeding (Table 2). At $24 \mathrm{~h}$ after a meal, there was no detectable GK activity in fish livers irrespective of diet composition, except in rainbow trout fed the highcarbohydrate diet in which the GK activity was slightly higher $24 \mathrm{~h}$ after feeding than $6 \mathrm{~h}$ after feeding (Table 2). As observed in Table 2, there were significant differences in glycemia of rainbow trout fed with carbohydrates (10.5 mM) compared with those fed without carbohydrates ( $4.3 \mathrm{mM})$ at $6 \mathrm{~h}$ after feeding. In common carp, no significant difference was observed, plasma glucose being low in the range of 2.5-3.5 mM. In contrast, at $6 \mathrm{~h}$ after feeding, the glycemia levels in gilthead seabream were high $(8.5 \mathrm{mM})$ in both groups fed with and without dietary carbohydrates. Therefore, we also investigated the relationship between GK activity and glycemia (Table 2): 1) in all fish species fed with carbohydrates as well as trout and carp fed without carbohydrates, a correlation coefficient of 0.67 between GK expression and glycemia was found; 2) strangely enough, in gilthead seabream fed without carbohydrates, there were still high glucose levels with absence of GK expression (Table 2).

Specific inhibition and tissue specificity of GK activity were also analyzed in the three fish species: 1) inhibition of hepatic GK activity was observed in frozen tissue with low $(5 \mathrm{mM})$ or high $(25 \mathrm{mM})$ concentrations of $\mathrm{N}$-acetyl glucosamine in gilthead seabream and rainbow trout, respectively, but not in common carp (Table 3); 2) GK activity was al most undetectablein the muscles of fish fed with carbohydrates (Table 4).

Total low- $\mathrm{K}_{m} \mathrm{HK}$ activities in livers were not dependent on either dietary carbohydrate levels or on the nutritional state (partially reflected by the time course

Table 3. Inhibition of hepatic GK activities by $\mathrm{N}$-acetyl-glucosaminein fish fed diets containing carbohydrates

\begin{tabular}{|c|c|c|c|c|c|c|c|}
\hline & \multicolumn{7}{|c|}{ GK Activities } \\
\hline & Control & 5 & 10 & 25 & 5 & 10 & 25 \\
\hline
\end{tabular}

Data are means of 5 observations ( 5 fishes) \pm SD in $\mathrm{mU} / \mathrm{mg}$ protein measured $6 \mathrm{~h}$ after feeding. Data are measured on frozen samples. $* \mathrm{P}<0.05, \dagger \mathrm{P}<0.01, \neq \mathrm{P}<0.001$ compared with control values. 
Table 4. Comparison of GK activities in two insulin-sensitivetissues of fish fed with carbohydrates

\begin{tabular}{lcc}
\hline \hline & \multicolumn{2}{c}{ GK Activities } \\
\cline { 2 - 3 } & Liver & Muscle \\
\hline Rainbow trout & $22.5 \pm 17.5$ & $0.2 \pm 0.1^{*}$ \\
Gilthead seabream & $16.0 \pm 5.5$ & $0.1 \pm 0.1^{*}$ \\
Common carp & $5.0 \pm 2.5$ & $0.8 \pm 0.6^{*}$ \\
\hline
\end{tabular}

Data are means of 3 observations ( 3 fishes) \pm SD in $\mathrm{mU} / \mathrm{mg}$ protein measured $6 \mathrm{~h}$ after feeding. Data are measured on frozen samples. $* \mathrm{P}<0.001$ compared with values in livers.

after feeding) in common carp (Table 5). In gilthead seabream, the HK activities are significantly lower $24 \mathrm{~h}$ after feeding than $6 \mathrm{~h}$ after feeding, and in rainbow trout, there is lower HK activity in fish fed without carbohydrates than in those fed with carbohydrates even $6 \mathrm{~h}$ after feeding. Overall, the differences between mean HK activities measured in distinct nutritional status are low compared with those between GK activities.

Data on GK gene expression as affected by nutritional status are reported in Figs. 1 and 2. There was no detectable GK gene expression in livers of fish fed without carbohydrates at $6 \mathrm{~h}$ after a meal (Fig. 1A). Carbohydrate feeding in rainbow trout and gilthead seabream induced a high expression of GK gene: 2.2and 2.7-kb mRNAs were detected in gilthead seabream and rainbow trout, respectively (Fig. 1A). GK gene expression was undetectable by Northern blotting in common carp (Fig. 1A). As Northern blotting was not sufficiently sensitive for the common carp, the expression of GK mRNA was confirmed by RT-PCR (Fig. 1B), but to bring out differences in GK mRNA levels between carp fed with or without carbohydrates would necessitate a quantitative RT-PCR analysis. The GK gene expression was also analyzed at $24 \mathrm{~h}$ after feeding (in a postabsorptive state) (Fig. 2). No hepatic GK gene expression was found by Northern blotting (data not shown) in all species fed without carbohydrates. In addition, time course of GK gene expression differed among fish fed with carbohydrates (Fig. 2). In rainbow trout, GK gene expression was persistent $24 \mathrm{~h}$ after a meal but threefold lower (analysis by densitometry) than that observed $6 \mathrm{~h}$ after feeding (Student's t-test,

Table 5. Total low $\mathrm{K}_{m} \mathrm{HK}$ activities in liver of threfish species fed diets with or without carbohydrates

\begin{tabular}{llccc}
\hline \hline & & \multicolumn{3}{c}{ Hours after Meal } \\
\cline { 3 - 5 } \multicolumn{1}{c}{ Species } & \multicolumn{1}{c}{ Diets } & 3 & 6 & 24 \\
\hline Rainbow trout & +Carbohydrates & ND & $2.1 \pm 1.6$ & $4.0 \pm 2.8$ \\
& -Carbohydrate & ND & $0.4 \pm 0.2 *$ & $3.4 \pm 2.7 \dagger$ \\
Gilthead & & & \\
seabream & +Carbohydrates & ND & $2.3 \pm 0.9$ & $1.3 \pm 0.7 \dagger$ \\
& - Carbohydrate & ND & $2.0 \pm 0.5$ & $1.1 \pm 0.8 \dagger$ \\
Common carp & +Carbohydrates & $5.1 \pm 1.4$ & $4.8 \pm 1.2$ & $5.3 \pm 1.4$ \\
& - Carbohydrate & $5.0 \pm 1.5$ & $7.2 \pm 4.6$ & $4.3 \pm 1.4$
\end{tabular}

Data are means of 9 observations ( 9 fishes) $\pm \mathrm{SD}$ in $\mathrm{mU} / \mathrm{mg}$ protein. Data are measured on fresh tissue. $\mathrm{K}_{\mathrm{m}}$, Michaelis constant; HK, hexokinase. $* \mathrm{P}<0.05$ compared with values of fish fed with carbohydrates; $\uparrow P<0.05$ compared with values at $6 \mathrm{~h}$ after feeding.
$\mathrm{P}<0.01$ ). In contrast, GK gene expression in gilthead seabream was undetectable at $24 \mathrm{~h}$ after feeding.

\section{DISCUSSION}

GK plays a major role in glucose homeostasis in mammals, and its deficiency has been linked to a form of diabetes in young men (41). Poor utilization of dietary carbohydrate in fish such as rainbow trout has been attributed to the absence of the GK enzyme (44). Our objective was to verify this hypothesis by analyzing the nutritional regulation of $\mathrm{HK}$ enzymes in hepatic tissue. Because different fish species are known to have different capacities of dietary carbohydrate utilization, comparisons were made with common carp and gilthead seabream.

Our data show that low- $\mathrm{K}_{\mathrm{m}} \mathrm{HK}$ activity in fish livers is not highly induced by food supply or dietary components, confirming previous reports of either slightly decreased HK activities (10) or absence of change (7, 35, 36) induced by nutritional factors. HK activity data (Table 5) are comparable to those obtained in Atlantic salmon (4 mU/mg protein) $(4,38)$. The constant activities of glucose phosphorylation at low glucose concentration are probably the results of $\mathrm{HK}-\mathrm{I}$ - and HK-III-like enzyme action as in mammals (43). In fact, we have partially cloned HK-I-like gene in hepatic tissues of common carp and gilthead seabream (3), confirming the existence of this type of HK enzymes in the two species.

The inhibition of GK activities by a specific inhibitor, the absence of GK expression in the muscles, and the induction of GK expression by dietary carbohydrates confirm the existence of a GK enzyme in rainbow trout and gilthead seabream. The GK expression in common carp is more complex: we observed an absence of inhibition of GK activity by $\mathrm{N}$-acetyl-glucosamine (on frozen samples) and a low GK activity even in fish fed with carbohydrates (on fresh samples). The absence of apparent GK inhibition by specific inhibitor in carp may be due to a low GK activity associated with high level of HK and glucose dehydrogenase activities in frozen tissues (36-38), which are known to be insensitive to $\mathrm{N}$-acetyl glucosamine. Concerning the low absolute values of GK activity measured in fresh livers of carp, the daily patterns of changes in enzyme activities allow us to observe a low induction of GK activity. Moreover, the recent cloning of the full-length GK cDNA in common carp (26) and the low GK gene expression observed in this study by RT-PCR prove irrefutably the existence of a mammalian-type GK gene in this species. Thus, overall, these data suggest strongly that the GK-like activity measured in "fresh" liver of common carp fed with carbohydrates is really a GK activity.

The unequivocal induction of GK activities in gilthead seabream and rainbow trout fed with carbohydrates is similar to data in mammals [for example, GK activity is $21.5 \pm 2.2 \mathrm{mU} / \mathrm{mg}$ in liver extracts from fed mice (9)]. The levels of induction of GK and HK activities found in Atlantic salmon [ 7-10 and 5 $\mathrm{mU} / \mathrm{mg}$ for GK and HK activities, respectively $(4,38)]$ 
A

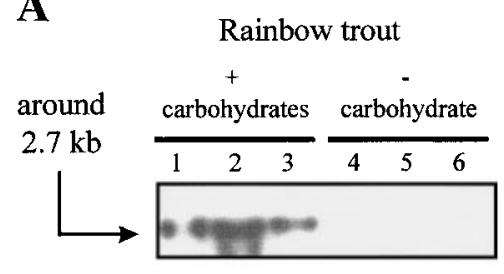

Gilthead seabream

$+$

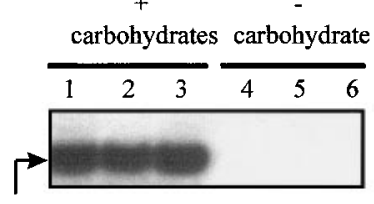

Common carp

carbohydrates carbohydrate

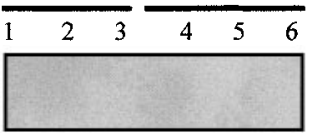

GK mRNA

around $2.2 \mathrm{~kb}$

B

Rainbow trout

$\stackrel{+}{\stackrel{-}{\text { carbohydrates }} \text { carbohydrate }}$

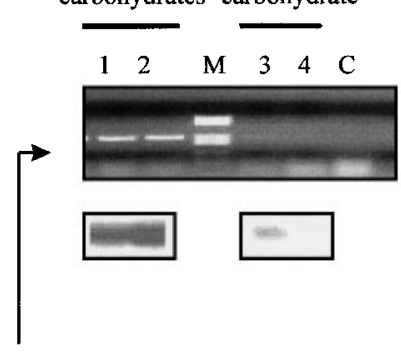

$239 \mathrm{bp}$

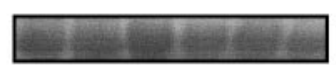

Gilthead seabream

$+$

carbohydrates carbohydrate

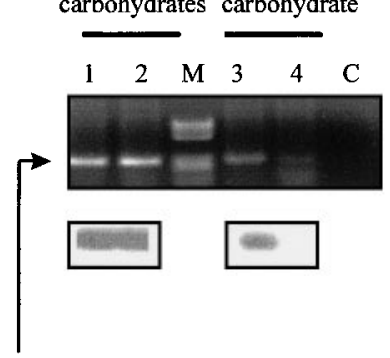

$243 \mathrm{bp}$

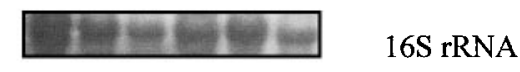

16S rRNA

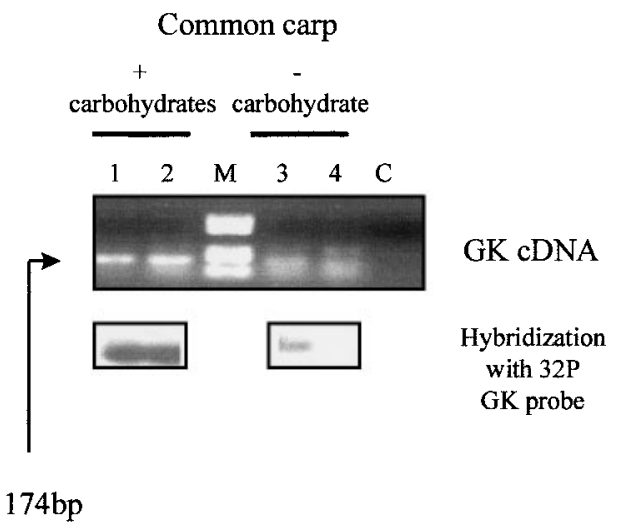

Fig. 1. Glucokinase (GK) gene expression in 3 species of fish fed with (+) or without (-) carbohydrates $6 \mathrm{~h}$ after feeding. A: GK gene expression analysis by Northern blotting (only 3 fish per group are shown). 16S rRNA served as internal control of sample loading. Numbers correspond to individuals. B: GK gene expression analysis by RT-PCR. PCR products were visualized by ethidium bromide or hybridized with ${ }^{32} \mathrm{P}$-labeled GK CDNA probes. M, molecular DNA weight marker V (Boehringer); C, negative control (RT-PCR without CDNA).

are similar to our results in carp. However, because no information on the interval after the meal is provided in the study by Tranulis et al. (38), we cannot make a precise comparison between the two studies. Induction of GK activities (and probably increasing of hepatic glucose storage) was suggested by significantly higher levels of hepatic glycogen in rainbow trout fed with carbohydrates than in those fed without carbohydrates $(8.2 \pm 1.0$ and $1.9 \pm 0.5 \%$, respectively, means \pm SD, $\mathrm{n}=9$ fish per group) $(\mathrm{P}<0.001)$ (these results are from the same study; F. Médale, unpublished observations). In carp, the low GK activity is also associated with low level of glycogen compared with rainbow trout (3.6 \pm $0.9 \%$ in carp fed with carbohydrates). Finally, the current evidence of inducible GK enzyme in fish is physiologically important, because, in mammals, it is generally assumed that GK expression is an absolute prerequisite for the effect of glucose (via a glucose metabolite) on glucose-regulated hepatic genes coding for glycolytic-lipogenic-gluconeogenic enzymes (14, 31, 33).

Another outcome of this study is the demonstration of a molecular regulation of GK gene expression, because the molecular regulation of GK synthesis is the main system regulating GK activity in mammals (16, 17, 30). As mentioned earlier, our own studies have shown the existence of GK genes in teleosts $(3,26)$. We found here that the rise of GK activity occurs concomi-
Rainbow trout
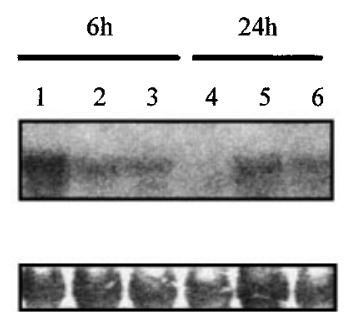

Gilthead seabream

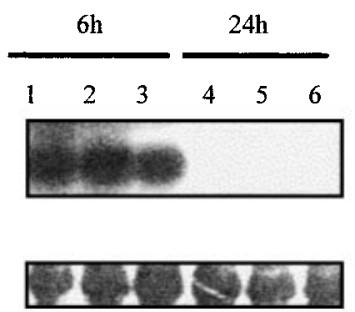

Common carp

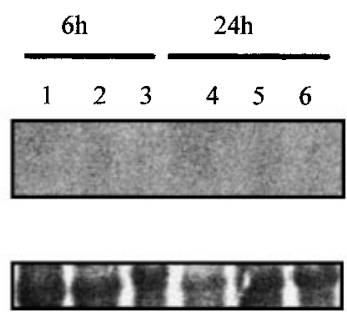

GK mRNA

\section{S rRNA}

Fig. 2. Time course of GK gene expression in 3 fish species fed diets with carbohydrates. Analysis by Northern blotting of fish livers at 6 and $24 \mathrm{~h}$ after feeding (only 3 fish per group are shown). Numbers correspond to individuals. When GK gene expression was found in 2 groups, an analysis by densitometry (Visio-Mic II software) was made. 
tantly with the accumulation of specific GK mRNA in rainbow trout and gilthead seabream, suggesting that the appearance of enzyme activity reflects the turning-on of GK genetranscription, as in mammals (16). To our knowledge, this is the first ever evidence in fish of a molecular regulation of a glycolytic enzyme related to an adaptation to dietary carbohydrates. The long-term adaptation (several weeks of feeding) is probably not necessary for induction of GK expression, as there is a time-dependent decrease of hepatic GK mRNA levels in fish fed dietary carbohydrates $24 \mathrm{~h}$ after a meal compared with $6 \mathrm{~h}$ after a meal (Fig. 2). So, a single meal may be sufficient to induce change in GK expression as observed in mammals $(17,30)$.

The question remains as to the influence of nutrient or hormonal factors implied in the induction of GK expression. Our data showed that there is high GK expression associated with dietary carbohydrate intake, one consequence of which is the relatively high levels of glycemia (except for the common carp) $(2,5$, 25). However, the relationship between glycemia and GK expression is somewhat complex. Although GK expression is high when there is a high level of glycemia in all fish species, the reverse is not true, at least in gilthead seabream. Indeed, there is persistent hyperglycemia in gilthead seabream fed without carbohydrates [the values of glycemia in fasted gilthead seabream is $\sim 4 \mathrm{mM}$ (F. Médale, personal communication)] associated with the absence of GK expression. The hyperglycemia in gilthead seabream fed without carbohydrates strongly suggests an intensive gluconeogenesis in seabream deprived of starch for a long time. Overall, it follows that dietary carbohydrate intake and not glyce mia per seis probably implied in GK induction in all the fish species. Consequently, levels of circulating hormones such as insulin or glucagon, which are both highly dependent on dietary composition, are presumably major factors involved in the induction of GK gene expression, as has been observed in mammals $(17,30)$. In vitro studies with hepatocytes might be of interest to distinguish direct versus indirect involvement of nutrient (glucose) and hormone (insulin, glucagon) on GK gene expression.

The efficiency of utilization of dietary carbohydrates is in the order common carp $>$ gilthead seabream $>$ rainbow trout $(11-13,44)$. The reverse order for postprandial glycemia (trout $>$ bream $>$ carp), as shown elsewhere $(2,5,25,44)$, is also seen with regard to GK expression. The more glucose-tolerant fish (common carp) had the lowest levels of induction of GK expression, whereas the theoretically less glucose-tolerant fish, such as rainbow trout, had the highest GK expression, even $24 \mathrm{~h}$ after feeding. Thus hepatic GK is probably neither the limiting step explaining the low dietary glucose utilization nor the major factor maintaining glycemia at low values in rainbow trout. In common carp, the GK expression is low, probably linked to an inherent strict control of glycemia as generally observed (44). Poor dietary carbohydrate utilization in rainbow trout undoubtedly involves other protein(s) either in liver or in other tissues than GK alone. It is possiblethat different fish species have different mechanisms to regulate blood glucose. Time course of action of insulin or other glucostatic systems can also be different between different species. Although activities of HK were higher in carp than in the other two species, the absence of any significant change in the activity of HK either due to the dietary carbohydrate level or at any postprandial stage (Table 5) would al so suggest that in this species the role of $\mathrm{HK}$ (s) might be different than in trout and seabream. Indeed, white muscle in rainbow trout, despite being quantitatively the major tissue, is known to poorly utilize dietary glucose as an energy source (44). Although HK activity in trout muscle has been found to exhibit the lowest activity of all the glycolytic enzymes (20), GLUT-4 glucose transporter was recently reported to be absent in muscle of tilapia (45), and there is also generally a low number of insulin receptors in the muscle of different teleosts (27). Globally, the exact contribution of liver in comparison with pancreatic $\beta$-cells and peripheral insulin-sensitive tissues (skeletal muscle and adipose tissue) to the observed hyperglycemia in rainbow trout requires further studies.

\section{Perspectives}

The demonstration of inducible hepatic GK enzyme in fish is a major step for further insight on the physiological regulation of glucose metabolism in teleosts. Advances in the field of regulatory mechanisms of glycolysis-gluconeogenesis pathways by glucose in glucose-intolerant animals such as fish makethis group an interesting model to study type II diabetes mellitus in humans. Further understanding of the nutritional regulation of glucose metabolism in tissues other than liver is again an important area of research. In addition, these studies bear strong practical implications, especially in the context of the replacement of fishmeals by plant protein sources rich in carbohydrates.

We are grateful to P. Ferré and Dr. F. L'H orset for encouragement and constructive criticism during preparation of the manuscript. We thank F. Vallée, F. Terrier, P. Rema, and J. Santinha for the maintenance of the rainbow trout (Institut $\mathrm{N}$ ational de la Recherche Agronomique experimental facilities), common carp (Vila Real, Portugal), and gilthead seabream (Olhao, Portugal). Also we acknowledge 1. Seiliez for technical assistance.

This work was supported by the European Commission (Fisheries Agricultural and Agro-I ndustrial Research, Contract FAI R No. CT950174) and the Aquitaine Region (No. CCRRDT: 960308003).

Address for reprint requests and other correspondence: S. Panserat, Fish Nutrition Laboratory, INRA-IFREMER, 64310 St-Pée-surNivelle, France (E-mail: panserat@st-pee.inra.fr).

Received 26 April 1999; accepted in final form 4 November 1999.

\section{REFERENCES}

1. Balkan B and Dunning BE. Glucosamine inhibits glucokinase in vitro and produces a glucose-specific impairment of in vivo insulin secretion in rats. Diabetes 43: 1173-1179, 1994.

2. Bergot F. Effects of dietary carbohydrates and of their mode of distribution on glycaemia in rainbow trout (Salmo gairdneri). Comp Biochem Physiol 64A: 543-547, 1979.

3. Blin C, Panserat S, Médale F, Gomes E, Breque J , Kaushik $\mathbf{S}$, and Krishnamoorthy R. Teleost liver hexokinase- and glucokinase-like enzymes: partial cDNA cloning and phylogenetic studies in rainbow trout (Onchorynchus mykiss), common 
carp (Cyprinus carpio) and gilthead seabream (Sparus aurata). Fish Physiol Biochem 21: 93-102, 1999.

4. Borrebaek B, Waagbo R, Christophersen B, Tranulis MA, and Hemre G. Adaptable hexokinase with low affinity for glucose in the liver of Atlantic salmon (Salmo salar). Comp Biochem Physiol 106B: 833- 836, 1993.

5. Brauge C, Corraze G, and Médale F. Effect of dietary levels of lipid and carbohydrate on growth performance, body composition, nitrogen excretion and plasma glucose levels in rainbow trout reared at 8 or $18^{\circ} \mathrm{C}$. Reprod Nutr Dev 35: 277-290, 1995.

6. Chomczynski $\mathbf{P}$ and Sacchi $\mathbf{M}$. Single step method of RNA isolation by acid guanidium thiocyanate phenol chloroform extraction. Anal Biochem 162: 156-159, 1987.

7. Cowey CB, Knox D, Walton MJ , and Adron J W. The regulation of gluconeogenesis by diet and insulin in rainbow trout. Br J Nutr 38: 463-470, 1977

8. Cowey CB and Walton MJ . Intermediary Metabolism, Fish Nutrition, edited by Halver E. New York: Academic, 1989, p. 259-329.

9. Ferre T, Riu E, Bosh F, and Valera A. Evidence from transgenic mice that glucokinase is ratelimiting for glucose utilization in the liver. FASE B J 10: 1213-1218, 1996.

10. Fideu MD, Soler G, and Ruiz-Amil T. Nutritional regulation of glycolysis in rainbow trout (Salmo gairdnieri R.). Fish Physiol Biochem 74B: 795-799, 1983.

11. Furuichi $\mathbf{M}$ and Yone $\mathbf{Y}$. Change of blood sugar and plasma insulin levels of fishes in glucose tolerance test. Bull J pn Soc Sci Fish 47: 761-764, 1981.

12. Furuichi $\mathbf{M}$ and Yone $\mathbf{Y}$. Effects of insulin on blood sugar levels in fishes. Bull J pn Soc Sci Fish 48: 1289-1291, 1982.

13. Furuichi $\mathbf{M}$ and Yone $\mathbf{Y}$. Changes in activities of hepatic enzymes related to carbohydrate metabolism of fishes in glucose and insulin-glucose tolerance tests. Bull J pn Soc Sci Fish 48: 463-466, 1982.

14. Girard J , Ferré P, and Foufelle F. Mechanisms by which carbohydrates regulate expression of genes for glycolytic and lipogenic enzymes. Annu Rev Nutr 17: 325-352, 1997.

15. Gruppe A, Hultgren B, Ryan A, Bauer M, and Stewart TA. Transgenic knockouts reveal a critical requirement for pancre atic $\beta$ cell glucokinase in maintaining glucose homeostasis. Cell 83: 69- 78, 1995.

16. Iynedjian P, Ucla C, and Mach B. Molecular cloning of glucokinase CDNA. Developmental and dietary regulation of glucokinase mRNA in rat liver. J Biol Chem 262: 6032-6038, 1987.

17. Iynedjian PB. Mammalian glucokinase and its gene. Biochem J 293: 1-13, 1993.

18. Magnuson MA. Tissue-specific regulation of glucokinase gene expression. J Cell Biochem 48: 115-121, 1992.

19. Matschinsky FM, Glaser B, and Magnuson MA. Pancreaticbeta-cell glucokinase: closing the gap between theoretical concepts and experimental realities. Diabetes 47: 307-315, 1998.

20. Moon TW and Foster GD. Tissue carbohydrate metabolism, gluconeogenesis and hormonal and environmental influences. In: Biochemistry and Molecular Biology of Fishes, edited by Hochachka PW and Mommsen TP. Amsterdam: Elsevier Science, 1995, p. 65-100.

21. Nagayama F and Ohshima $\mathbf{H}$. Studies on the enzyme system of carbohydrates metabolism in fish. I. Properties of liver hexokinase. Bull J pn Soc Sci Fish 40: 285-290, 1974.

22. Nagayama F, Ohshima H, Suzuki H, and Ohshima T. A hexokinase from fish liver with wide specificity for nucleotides as phosphoryl donor. Biochim Biophys Acta 615: 85-93, 1980.

23. National Research Council. Nutrient Requirements of Fish. Washington, DC: National Academy Press, 1993.

24. Niswender KD, Shiota M, Postic C, Cherrington AD, and Magnuson MA. Effects of increased glucokinase gene copy number on glucose homeostasis and hepatic glucose metabolism. J Biol Chem 272: 22570-22575, 1997.

25. Palmer TN and Ryman BE. Studies on glucose intolerance in fish. J Fish Biol 4: 311-319, 1972.

26. Panserat S, Blin C, Médale F, Plagnes-J uan E, Brèque J , Krishnamoorthy $\mathbf{R}$, and Kaushik S. Molecular cloning, tissue distribution and sequence analysis of complete glucokinase cDNAs from rainbow trout (Oncorhyncus mykiss), gilthead seabream (Sparus aurata) and common carp (Cyprinus carpio). Biochim Biophys Acta 1474: 61-69, 2000.

27. Parrizas M, Planas J , Plisetskaya EM, and Gutierrez J . Insulin binding and receptor tyrosine kinase activity in skel etal muscle of carnivorous and omnivorous fish. AmJ Physiol Regulatory IntegrativeComp Physiol 266: R1944-R1950, 1994.

28. Piston DW, Knobel SM, Postic C, Shelton KD, and Magnuson MA. Adenovirus-mediated knockout of a conditional glucokinase gene in isolated pancreatic islets reveals an essential role for proximal metabolic coupling events in glucose-stimulated insulin secretion. J Biol Chem 274: 1000- 1004, 1999.

29. Postic C, Shiota M, Niswender KD, J ettob TL, Chen Y, Moates J M, Shelton KD, Lindner J , Cherringtona AD, and Magnuson MA. Dual roles for glucokinase in glucose homeostasis as determined by liver and pancreatic beta-cell specific gene knock-outs using cre recombinase. J Biol Chem 274: 305-315, 1999.

30. Printz RL, Magnuson MA, and Granner DK. Mammalian glucokinase. Annu Rev Nutr 13: 463-496, 1993.

31. Rencurel $\mathbf{F}$ and Girard J . Regulation of liver gene expression by glucose. Proc Nutr Soc 57: 265-275, 1998.

32. Sanger F, Nicklen S, and Coulson AR. DNA sequencing with chain terminating inhibitors. Proc Natl Acad Sci USA 74: 5463-5467, 1977.

33. Scott DK, O'Doherty RM, Stafford J M, Newgard CB, and Granner DK. The repression of hormone-activiated PEPCK gene expression by glucose is insulin-independant but requires glucose metabolism. J Biol Chem 273: 24145-24151, 1998.

34. Suarez RK and Mommsen TP. Gluconeogenesis in teleost fishes. Can J Zool 65: 1869-1882, 1987.

35. Sundby A, Hemre G, Borrebaek B, Christophersen B, and Blom A. Insulin and glucagon family peptides in relation to activities of hepatic hexokinase and other enzymes in fed and starved atlantic salmon (Salmo salar) and cod (Gadus morhua). Comp Biochem Physiol 100B: 467-470, 1991.

36. Tranulis MA, Christophersen B, B lom B, and Borrebaek B. Glucose dehydrogenase, glucose-6-phosphate dehydrogenase and hexokinase in liver of rainbow trout (Salmo gairdneri). Effects of starvation and temperature variations. Comp Biochem Physiol 99B: 687-691, 1991.

37. Tranulis MA, Christophersen B, and Borrebaek B. Glucose dehydrogenase in beef (Bos taurus) and rainbow trout (Oncorhynchus mykiss) liver: a comparative study. Comp Biochem Physiol 109B: 427-435, 1994.

38. Tranulis MA, Dregni O, Christophersen B, Krogdahl A, and Borrebaek B. A glucokinase-like enzyme in the liver of Atlantic salmon (Salmo salar). Comp Biochem Physiol 114B: 35-39, 1996.

39. Tranulis MA, Christophersen B, and Borrebaek B. Glucokinase in Atlantic halibut (Hippogl ossus hippogl ossus) Brockmann bodies. Comp Biochem Physiol 116B: 367-370, 1997.

40. Vandercammen A and Van Schaftingen E. Species and tissue distribution of the regulatory protein of glucokinase. Biochem J 294: 551-556, 1993.

41. Vionnet N, Stoffel M, Takeda J , Yasuda K, Bell GI, Zouali H, Lesage S, Velho G, Iris F, Passa P, Froguel P, and Cohen D. Nonsense mutation in the glucokinase gene causes early-onsetnon-insulin-dependent diabetes mellitus. Nature 356: 721-722, 1992.

42. West TG, Brauner $\mathbf{C} \boldsymbol{J}$, and Hochachka PW. Muscle glucose utilization during sustained swimming in the carp (Cyprinus carpio). Am J Physiol Regulatory Integrative Comp Physiol 267: R1226-R1234, 1994.

43. Wilson J E. Hexokinases. Rev Physiol Biochem Pharmacol 126: 65-198, 1995.

44. Wilson RP. Utilisation of dietary carbohydrate by fish. Aquaculture 124: 67-80, 1994

45. Wright J R, O'Hali W, Yuang H, Han X, and Bonen A. Glut-4 deficiency and severe peripheral resistance to insulin in the teleost fish tilapia. Gen Comp Endocrinol 111: 20-27, 1998. 